INTERNATIONAL RESEARCH JOURNAL OF PHARMACY

\title{
ANTIULCER ACTIVITY OF AQUEOUS EXTRACT OF FRESH LEAF OF BRASSICA OLERACEAE LINN. VAR. ACEPHALA (D.C) ALEF) (BRASSICACEAE)
}

Agbaje, Esther Oluwatoyin*, Okpara, Chioma Sonia

Department of Pharmacology, College of Medicine of the University of Lagos, P.M.B. 12003, Idiaraba, Lagos Nigeria

*Corresponding Author Email: estheragbaje@gmail.com

Article Received on: 19/06/13 Revised on: 21/07/13 Approved for publication: 21/08/13

DOI: $10.7897 / 2230-8407.04818$

IRJP is an official publication of Moksha Publishing House. Website: www.mokshaph.com

(C) All rights reserved.

\section{ABSTRACT}

Brassica oleraceae (BOL) is the common cabbage and a familiar garden plant, widely used as spice all over the world. Cabbage is an excellent source of Vitamin $\mathrm{C}$ and has been widely employed locally to treat acute inflammation and peptic ulcers. The present study aimed at evaluating the antiulcer activity of Brassica oleraceae, while identifying the phytoconstituents responsible for the observed effects and exploring some of the possible mechanisms of its antiulcer activity, using standard laboratory procedures. Doses of 100, 300 and $750 \mathrm{mg} / \mathrm{kg}$ of Brassica oleraceae were separately administered to groups of overnight fasted rats, with appropriate standard drugs using Ethanol / $\mathrm{HCl}$, Indomethacin and Cysteamine models to explore antiulcer property of BOL on the stomach and duodenum respectively. The extract in a dose dependent fashion, offered better protection against the ulcerogens in the gastric ulcer models, when compared with the positive control groups. However, the smallest dose of $100 \mathrm{mg} / \mathrm{kg}$ recorded the highest percentage protection in the cysteamine group. Up to $1200 \mathrm{mg} / \mathrm{kg}$ i.p and $10,000 \mathrm{mg} / \mathrm{kg}$ oral doses of Brassica oleraceae did not produce any mortality in mice. Phytochemical constituents identified included alkaloids, tannins, cardiac glycosides, flavonoids, phlobatannins, anthraquinones and saponins. The pH was 8.5 . The present study has validated the local use of Brassica oleraceae in the treatment of peptic ulcer and the speculated mechanisms of action could be through acid neutralization, cytoprotection and antioxidation by flavonoids.

Keywords: Gastric ulcer, Duodenal ulcer, Ulcerogen, Brassica oleraceae Extract, Rat, Phytoconstituents.

\section{INTRODUCTION}

Ulcers are crater-like sores on the skin and mucous membrane. Peptic ulcer disease (PUD), the most prevalent gastrointestinal (GI) disorder ${ }^{1}$ ensues when the stomach and duodenum are affected. For over a century, PUD has been one of the leading causes of GI surgery, with high morbidity and mortality rates. It affects several people worldwide and some researchers consider it a new plague of the twenty first century $^{2,3}$. Pathophysiology of PUD involves an imbalance between the protective factors (mucin, prostaglandin, growth factors, nitric oxide and bicarbonate) and aggressive factors (acid, pepsin and Helicobacter pylori) in the stomach ${ }^{4}$. Provocative factors could also aggravate the pathological state of the individual ${ }^{5}$ for example, use of drugs such as the non steriodal anti inflammatory agents, alcohol, cigarette smoking and stress ${ }^{6}$. There have been two main approaches for treating PUD; one deals with reducing the production of gastric acid and mopping up of any excess acid secreted (proton pump inhibitors, histamine $\mathrm{H}_{2}$ receptor antagonists, and antacids), while the second involves reinforcing the gastric mucosal protection (prostaglandin analogues, and cytoprotective agents) $)^{1,3}$. Conventional treatments have a number of limitations; for example, long-term and / or high dose administration often record several GI adverse effects, including small bowel bacterial overgrowth, spontaneous bacterial peritonitis, vitamin $\mathrm{B}_{12}$ deficiency, community acquired pneumonia and the risks of Clostridium officile colitis $^{7,8}$. Herbal medicine is fast emerging as an alternative to available synthetic drugs used for treating diverse ailments and diseases, including peptic ulcer, possibly due to low cost, ready availability, and their speculated effectiveness 9 . A great variety of medicinal plants used, either the whole plant or a specific part of it (root, stem, leaf, seed, fruit and flower) is formulated into suitable preparations, which could be compressed as tablets or made into pills, infusions, extracts and tinctures among other uses. These drugs may be slow in action, but most of them compare effectively with standard medications and are reliable with relative safety. The plant Brassica oleraceae (BOL) is the cultivated cabbage derived from a leafy plant called the wild mustard plant, sea cabbage and wild cabbage. It is native to the Mediterranean region along the seacoast. It is often considered one of the most ancient plants among all the common vegetables used by man, since history revealed that the consumption of cabbage by humans in the eastern world may have been as early as four millennia ago. Furthermore, it has been employed as an herbal remedy for the prevention and treatment of various diseases and disorders including arthritis, scurvy, leg ulcers, asthma, colitis, cough, peptic ulcer, acne, and constipation in different parts of the world ${ }^{10}$. Breast milk production was usually enhanced by giving cabbage to expectant mothers ${ }^{11}$. The present study sought to investigate the anti ulcer activity of Brassica oleraceae in laboratory-induced gastric and duodenal ulcers, using standard experimental models, as well as elucidating the probable mechanisms of its antiulcer action.

\section{MATERIALS AND METHODS \\ Preparation of Plant Extract}

The plant Brassica oleraceae was obtained from the Vegetable Garden City in Lagos Metropolis, Lagos-Nigeria, and was identified by Mr. T.K. Odewo of the Department of Botany and Microbiology, University of Lagos, with voucher number LUH 2746. Fresh clean leaves of the plant were weighed $(3 \mathrm{~kg})$, chopped into bits and blended to obtain a mash of cabbage juice. Distilled water $(0.9 \mathrm{~L})$ was added to facilitate blending. The resultant juice was sieved through a sterile cotton wool, placed in a funnel to separate the residues and sediments from the juice and thereafter a clean handkerchief was employed to further sieve the juice to obtain the eventual fine pure cabbage juice used in the study. The juice was afterwards dried in the oven at $40^{\circ} \mathrm{C}$, weighed, and stocked airtight in the freezer, as Brassica oleraceae 
extract, until ready for use. Percentage yield and $\mathrm{pH}$ of the extract were recorded.

\section{Animals}

Healthy Wistar mice and Sprague Dawley rats of both sexes purchased from Laboratory Animal Centre, College of Medicine, University of Lagos, Lagos, Nigeria and weighing 15-20 g and 100-150 g respectively were used for the study. All animals were maintained under standard laboratory conditions (temperature $25 \pm 2{ }^{\circ} \mathrm{C}$ ) and humidity $(55 \pm 5 \%$ ), with $12 \mathrm{~h}$ day: $12 \mathrm{~h}$ night cycle. The animals were fed with the normal laboratory diet (Ladokun Feeds PLC, Ibadan-Nigeria) and drinking water ad libitum. All the experimental procedures were in strict accordance with Institutional Animal Ethical Committee Guidelines for the care and use of laboratory animals.

\section{Phytochemical Screening}

The aqueous extract was tested for the presence or absence of secondary metabolites using standard phytochemical procedures $^{12,13}$.

\section{Acute Toxicity Test}

Toxicity of the plant was determined using a standardized method $^{14}$. Doses of 300,600 and $1200 \mathrm{mg} / \mathrm{kg}$ were given intraperitoneally (i.p) and up to $10,000 \mathrm{mg} / \mathrm{kg}$ administered orally to groups of fasted rats, which were thereafter monitored for behavioural changes, toxic symptoms and mortality.

\section{Antiulcer Activity Study \\ Ethanol / HCl-induced gastric ulcer (Protective)}

Six groups of rats $(n=5)$ were randomly selected and treated orally as follows: Group 1: Distilled water $10 \mathrm{ml} / \mathrm{kg}$, Group 2: Cimetidine $100 \mathrm{mg} / \mathrm{kg}$, Group 3: Omeprazole $20 \mathrm{mg} / \mathrm{kg}$, Group 4: Brassica oleraceae $100 \mathrm{mg} / \mathrm{kg}$, Group 5: Brassica oleraceae $300 \mathrm{mg}$ / kg, Group 6: Brassica oleraceae $750 \mathrm{mg}$
$/ \mathrm{kg}$. One hour after gavage, one millilitre of $70 \%$ ethanol in $250 \mathrm{mM} \mathrm{HCl}$ was delivered via oral cannula to the stomach of all the animals and the animals were humanely sacrificed 1 $\mathrm{h}$ later. The stomachs were dissected along the greater curvature and rinsed in normal saline in order to observe and score the lesions produced ${ }^{15}$.

\section{Ethanol / HCl-Induced Gastric Ulcers (Curative)}

Thirty rats were divided into two groups of 15 each, for distilled water (control) and Brassica oleraceae $750 \mathrm{mg} / \mathrm{kg}$, respectively given $1 \mathrm{~h}$ after the ulcerogen ethanol $/ \mathrm{HCl}^{16}$. Five animals were randomly selected from each group 4 h, 24 $\mathrm{h}$ and $72 \mathrm{~h}$ after drug therapy, and sacrificed with the stomach examined to determine the curative properties of the herbal drug, viz-a-viz, its time of onset and duration of action. Ulcer was scored as earlier described ${ }^{1,15}$.

\section{Indomethacin-induced gastric ulcers}

Groups of animals were given Brassica oleraceae 100, 300 and $750 \mathrm{mg} / \mathrm{kg}$, distilled water $10 \mathrm{ml} / \mathrm{kg}$ (negative control) and misoprostol $200 \mu \mathrm{g} \mathrm{/} \mathrm{kg}$ the positive control. Indomethacin $50 \mathrm{mg} / \mathrm{kg}$ was administered $1 \mathrm{~h}$ after the various test agents ${ }^{17}$ and all animals were sacrificed $6 \mathrm{~h}$ afterwards for ulcer scoring.

\section{Cysteamine-induced duodenal ulcer}

Randomly selected groups of animals were treated with 400 $\mathrm{mg} / \mathrm{kg}$ cysteamine and $1 \mathrm{~h}$ after; rats were dosed as before with Brassica oleraceae and with $20 \mathrm{mg} / \mathrm{kg}$ omeprazole as the standard drug. Twenty four hours later, the animals were sacrificed and their duodena opened along the mesenteric side to observe and score the lesions ${ }^{18}$.

\section{Statistical Analysis of Results}

Analysis was done using the unpaired student's t-test and significance of difference was accepted as $\mathrm{p}<0.05$.

Table 1: Effect of Brassica oleraceae on Ethanol / HCl-induced gastric ulcer (protective)

\begin{tabular}{|c|c|c|}
\hline Drug / Dose (mg / kg) & Ulcer index & \% Protection \\
\hline Distilled water $10 \mathrm{ml} / \mathrm{kg}$ & 35 & 0 \\
\hline Cimetidine 100 & $* 21$ & 40 \\
\hline Omeprazole 20 & $* 20$ & 42.9 \\
\hline Brassica oleraceae 100 & $* 20$ & 42.9 \\
\hline Brassica oleraceae 300 & $* 18$ & 48.6 \\
\hline Brassica oleraceae 750 & $* 16$ & 54.3 \\
\hline \multicolumn{2}{|c|}{$\mathrm{P}<0.05$ when compared with control } \\
\hline
\end{tabular}

Table 2: Effect of Brassica oleraceae on Indomethacin-induced gastric ulcer

\begin{tabular}{|c|c|c|}
\hline Drug / Dose (mg / kg) & Ulcer index & \% Protection \\
\hline DW & 16 & 0 \\
\hline Misoprostol 0.2 & $* 2.5$ & 84 \\
\hline Brassica oleraceae 100 & $* 10.5$ & 34.4 \\
\hline Brassica oleraceae 300 & $* 6.5$ & 59.3 \\
\hline Brassica oleraceae 750 & $\mathrm{a},{ }^{*} 1.5$ & 90.6 \\
\hline $\mathrm{a},{ }^{*} \mathrm{p}<0.05$ when compared with misoprostol and control respectively \\
\hline
\end{tabular}

Table 3: Effect of Brassica oleraceae on cysteamine-induced duodenal ulcer

\begin{tabular}{|c|c|c|}
\hline Drug / Dose (mg / kg) & Ulcer index & \% Protection \\
\hline DW & 75 & 0 \\
\hline Omeprazole 20 & $* 20.5$ & 45 \\
\hline Brassica oleraceae 100 & $* 5.5$ & 85 \\
\hline Brassica oleraceae 300 & $* 12.5$ & 67 \\
\hline Brassica oleraceae 750 & $* 19.5$ & 48 \\
\hline
\end{tabular}

Table 4: Curative effect of Brassica oleraceae on Ethanol / HCl-induced gastric ulcer

\begin{tabular}{|c|c|c|c|}
\hline Test Agents & \multicolumn{3}{|c|}{ Post drug therapy / ulcer index } \\
\hline & $4 \mathrm{~h}$ & $24 \mathrm{~h}$ & $72 \mathrm{~h}$ \\
\hline DW & 12 & 6 & 1.5 \\
\hline Brassica oleraceae $750 \mathrm{mg} / \mathrm{kg}$ & $* 1.5$ & 0 & 0 \\
\hline$\%$ Protection & 87.5 & 100 & 100 \\
\hline \multirow{2}{*}{$\mathrm{p}<0.05$ when compared with control } & \\
\hline
\end{tabular}




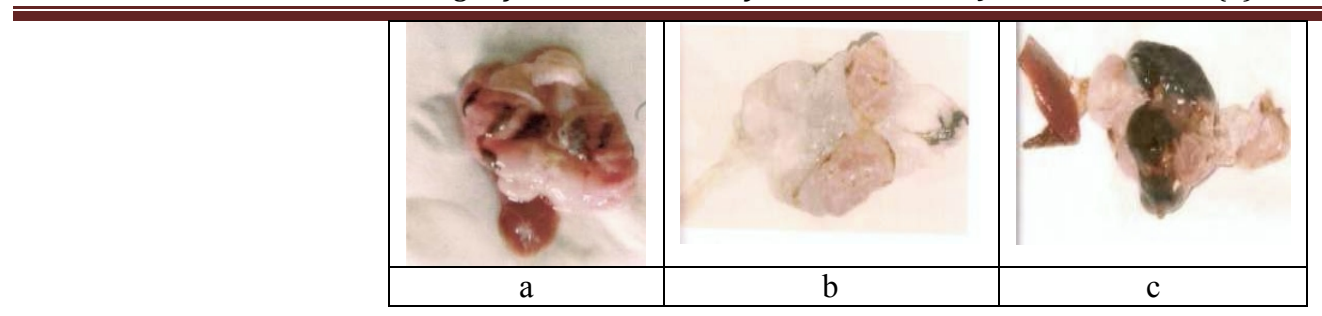

Figure 1: Ethanol / $\mathrm{HCl}$ induced gastric ulcer (Protective) $\neg$ a and $b=300$ and $750 \mathrm{mg} / \mathrm{kg}$ Brassica oleraceae respectively, $\mathrm{c}$ is Distilled water (negative control)

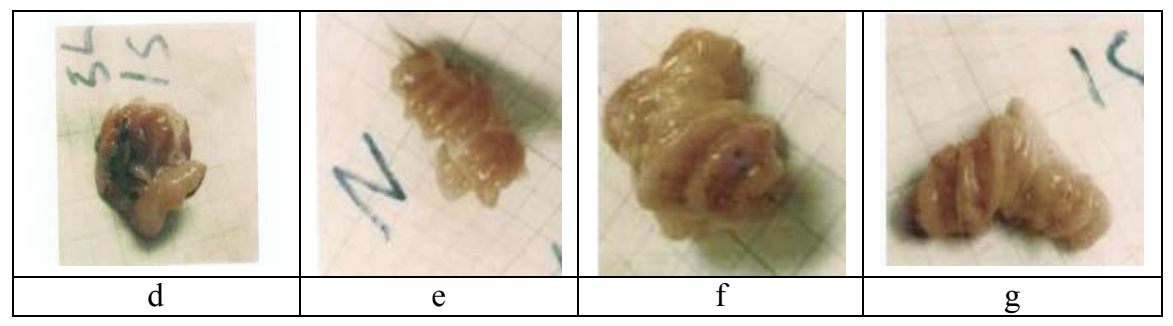

Figure 2: Indomethacin-induced gastric ulcer (Protective) d is distilled water (negative control), e and $\mathbf{f}=750$ and $300 \mathrm{mg} / \mathrm{kg}$ Brassica oleraceae respectively, $\mathrm{g}$ is misoprostol (positive control).

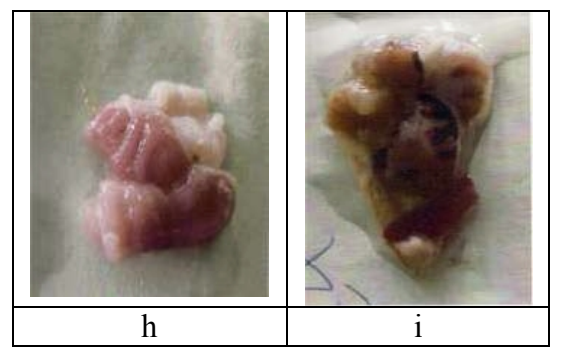

Figure 3: Ethanol / HCL-induced gastric ulcer (Curative) h and $\mathrm{i}=\mathbf{7 5 0} \mathrm{mg} / \mathrm{kg}$ Brassica oleraceae and distilled water (negative control) $4 \mathrm{~h}$ post therapy

\section{RESULTS}

The extract, completely dissolved in distilled water and recorded a $\mathrm{pH}$ of 8.5

\section{Acute Toxicity}

No lethality was produced by i.p administration of Brassica oleraceae, except mild sedation and itching, both of which were transient.

\section{Phytochemical Screening}

Alkaloids, tannins, cardiac glycosides, flavonoids, phlobatanins, anthraquinones and saponins were identified.

Antiulcer Activity of Brassica oleraceae Ethanol / HCl-induced gastric ulcer (Protective)

The herbal preparation yielded a dose-dependent and significant effect when compared with the negative control group. In addition, its effect, especially in doses of 300 and $750 \mathrm{mg} / \mathrm{kg}$, was superior to the standard drugs cimetidine and omeprazole (Table 1).

\section{Effect of Brassica oleraceae on Indomethacin-induced gastric ulcer}

The plant drug recorded a significant antiulcer activity when compared with both the negative and positive control groups (Table 2, Figure 2). The highest dose of Brassica oleraceae produced a higher efficacy than misoprostol.

\section{Cysteamine-induced duodenal ulcer}

Efficacy reduced with increasing doses, and $100 \mathrm{mg} / \mathrm{kg}$, the least dose of Brassica oleraceae employed in this study gave $85.3 \%$ efficacy. Omeprazole, the standard drug used recorded only $45 \%$ effect (Table 3 ).

\section{Curative Property of Brassica oleraceae in Ethanol /} HCL-induced gastric ulcer

The herbal preparation possessed a relatively fast onset of action, since $87.5 \%$ protection was recorded within $4 \mathrm{~h}$ of drug administration. The herbal drug antiulcer effect was also sustained as all the sores were totally cleared by $24 \mathrm{~h}$. (Table 4, Figure 3).

\section{DISCUSSION}

BOL (Cabbage) is a local vegetable used as spice by majority of people, who may not necessarily have any knowledge of its medicinal benefits. Administration of the aqueous extract up to $10,000 \mathrm{mg} / \mathrm{kg}$ did not produce any mortality in the animals, which showed its relative safety. The present investigation explored both the protective and curative potentials of Brassica oleraceae in laboratory-induced ulcers, while employing ethanol / $\mathrm{HCl}$ and indomethacin as ulcerogens in gastric ulcers, and cysteamine $\mathrm{HCl}$ in duodenal ulcers. Brassica oleraceae, in a dose dependent fashion protected against ulcer in both the gastric ulcer models, however, a higher efficacy was recorded in the indomethacin model, where the highest dose of the herbal drug, $750 \mathrm{mg} /$ $\mathrm{kg}$ produced $90.6 \%$ antiulcer effect, which was not only significant when compared with both the negative and 
positive control groups, but also better than misoprostol, the standard drug used. Ethanol and $\mathrm{HCl}$, the most common necrotizing agents produce severe gastric erosions when given intragastrically. Oxygen-free radicals which lead to an increased lipid peroxidation and damage to cell and cell membranes, are implicated in the pathogenesis of ethanol / $\mathrm{HCl}$-induced gastric mucosal injury ${ }^{19}$. Ethanol $/ \mathrm{HCl}$, in addition to its direct damage of gastric mucosal cells through free radicals formation, also causes solubilisation of mucus constituents and depresses tissue levels of proteins, leading to flow stasis in gastric blood ${ }^{19}$. Flavonoids, one of the phytoconstituents in Brassica oleraceae, have been confirmed to possess anti ulcerogenic property through cytoprotection, free radical scavenging and antioxidation, also through increased mucus production, antisecretory actions, and inhibition of the Helicobacter pylori growth ${ }^{20,21}$. Furthermore, Vitamin $\mathrm{C}$, an antioxidant has also been reported present in Brassica oleraceae ${ }^{12}$ and the herbal drug has been observed to produce antimicrobial activity ${ }^{22}$. Tannins another group of constituents in Brassica oleraceae, prevent ulcer formation as a result of their protein precipitating and vasoconstricting effects; ${ }^{23}$ their astringent action helps to precipitate microproteins on the ulcer site, thereby, forming an impervious layer over the lining, which hinders induced gastric ulcer in rats ${ }^{23}$. Indomethacin produces gastric lesions by inhibiting the synthesis of cytoprotective prostaglandins through modulation of cyclooxygenase isoforms, $\mathrm{COX}_{1}$ and $\mathrm{COX}_{2}$; infiltrating inflammatory cells, and the involvement of inducible nitric oxide synthase (iNOS) and its products. Therefore, involvement of oxygen derived free radicals such as the superoxide anion, hydrogen peroxide, and hydroxyl radical are well established in the pathogenesis of nonsteroidal anti inflammatory drug-induced ulcer. The resulting products, through oxidative stress produce gastric mucosal lesions, leading to disruption of gastric mucosal barrier. Agents which have cytoprotective and/or antacid secretory effect, prevent gastric lesions induced by indomethacin ${ }^{12}$. Fresh cabbage juice has also been reported to contain zinc, phosphorus, glutamine and S-methyl methionine $^{12}$ all of which enhance antiulcer activity via different mechanisms. In cysteamine-induced duodenal ulcer, the herbal drug's efficacy was similarly sustained. Mechanism of ulcer formation in this model has been shown to involve an increase of oxygen-derived free radicals and a decrease of $\mathrm{Cu}, \mathrm{Zn}$, and superoxide dismutase (SOD) activity in the duodenal mucosa ${ }^{18,24}$. Other factors involved include increased duodenal motility ${ }^{31}$ decreased duodenal bicarbonate secretion in response to acid ${ }^{25,26}$ delayed gastric emptying and enhanced or unchanged gastric secretion. The protective effect of Brassica oleraceae against cysteamine-induced duodenal ulcers could be due to the strengthening of the duodenal mucosa or by other mechanisms like increased gastric and duodenal alkaline secretion or by increased luminal prostaglandin levels ${ }^{18,27}$. Brassica oleraceae recorded a $\mathrm{pH}$ of 8.5 and its antiinflammatory property has been well documented $^{28}$.

\section{CONCLUSION}

The present study has shown the antiulcer property of Brassica oleraceae and the findings may support the local use of Brassica oleraceae in treating peptic ulcer disease. It also demonstrated the superiority and safety of Brassica oleraceae over the commonly used conventional antiulcer drugs and has been able to suggest some of the possible pathways for Brassica oleraceae antiulcer activity.
Nevertheless, further studies on kinetics and safety (subacute and chronic toxicity studies involving the evaluation of the haematological and biochemical parameters) are necessary.

\section{REFERENCES}

1. Heloina De Sousa Falcao, Jacqueline Alves Leite, Jose Maria Barbosa Filho, Petronio Filgueiras De Athayde Filho, Maria Celia De Oliveira Chaves, Marcelo Dantas Moura et al. Gastric and Duodenal Antiulcer Activity of Alkaloids: A Review. Molecules 2008; 13(12): 3198-3223. http://dx.doi.org/10.3390/molecules13123198 PMid:19104486

2. Malley OP. Gastric ulcers and GERD. The new plagues of the $21^{\text {st }}$ century update for the clinical nurse specialist. Clin. Nurse Spec. 2003; 17: 286289. http://dx.doi.org/10.1097/00002800-200311000-00008

3. Sumbul S, Ahmad MA, Asif M, Akhtar M. Role of phenolic compounds in peptic ulcer. An overview. J. Pharm. Bio. Allied Sci. 2011; 3(3): 361367.

4. Umamaheswari M, Asokkumar K, Rathidevi R, Sivashanmugam AT, Subhadradevi V, Ravi TK. Antiulcer and in-vitro antioxidant activities of Jasminum grandiflorum L. J. Ethnopharmacol. 2007; 110(3): 464470. http://dx.doi.org/10.1016/j.jep.2006.10.017 PMid:17125945

5. Berardi RR, Welage S. Peptic Ulcer Disease.In: Dipiro, TJ, RL Talbert, G Yees, G Matzke, G Wells and M Posey, (Eds.), Pharmacotherapy: A Pathophysiologic Approach. $6^{\text {th }}$ ed., McGrawHill; 2005. p. 629648.

6. Hiruma Lima CA, Calvo TR, Rodrigues CM, Andrade FDP, Vilegas W, Brito ARMS. Antiulcerogenic activity of Alchornea castaneaefolia effects of somatostatin, gastrin and Prostaglandin. J. Ethnopharmacol 2006; 104(1-2): 215-224. http://dx.doi.org/10.1016/j.jep.2005.09.007 PMid:16253451

7. Santin JR, Lemos M, Junior LCK, Niero R, de Andrade SF. Antiulcer effects of Achyrocline satureoides (Lam) DC (Asteraceae) (Marcela), a folk medicine plant in different experimental models. J. Ethnopharmacol 2010; 130(2): 334-339. http://dx.doi.org/10.1016/j.jep.2010.05.014 PMid:20546870

8. Denis MC. Adverse effects of proton pump inhibitor drugs: Clues and Conclusions. Curr. Opin. Gastroenterol 2010; 26: 624631.

9. Falcao HS, Mariath IR, Diniz MFFM, Batista LM, Barbosa Filho JM. Plants of the American continent with Antiulcer Activity. Phytomedicine 2008; 15: 132-146. http://dx.doi.org/10.1016/ j.phymed.2007.07.057 PMid:17904832

10. Ou B, Huang D, Hampsch Woodill M, Flanagan J, Deemer E. Analysis of antioxidant activities of common vegetables employing oxygen radical absorbance capacity (ORAC) and ferric reducing antioxidant power (FRAP) assays: A comparative study. J. Afr. Food Chem 2002; 50: 31223128.

11. KrisEtherton, PM, Hecker KD, Bonanome A. Bioactive compounds in foods: their role in the prevention of cardiovascular disease and cancer. Am. J. Med 2002; 113: 7188.

12. Singh J, Upadhyay AK, Bahadur A, Singh B, Singh KP, Rai M. Antioxidant phytochemicals in cabbage (Brassica oleraceae L. Var capitata) Scientia Horticulturae 2006; 108: 233237.

13. Harbourne JB. Phytochemical Methods. A Guide to modern techniques of plant analysis, 2ed. Chapmann and Hall, London; 1984. p. 192. http://dx.doi.org/10.1007/978-94-009-5570-7

14. Miller LC, Tainter ML. Estimation of ED50 and its error by means of logarithmic probit graph paper. Proc. Soc. Exp. Biol. (N.Y.) 1944; 57: 261264 .

15. Vidya Ignatius, Madhusudhanan Narayana, Venkataraman Subramanian, Balasubramanian Mairuthaiveeran Periyasamy. Antiulcer Activity of Indigenous plant Operculina turpenthum Linn. Evidence-Based Complementary and Alternative Medicine; 2013. Article ID 272134, 7 pages. http://dx.doi.org/10.1155/2013/272134

16. Siminialayi IM and Agbaje EO. Gastroprotective effects of the Ethanolic extract of Enantia chlorantha in rats. W. Afr. Pharmacol. Drug Res 2004; 1 and 2: 3538 .

17. Parmar NS, Parmar S. Antiulcer activity of Tephrosia purpurea in rats. Ind. J. Physiol Pharmacol 1998; 48: 343351.

18. Briden S, Flemstrom G, Kivilaasko E. Cysteamine and propioniotrile inhibit the rise of duodenal mucosal alkaline secretion in response to luminal acid in rats. Gastroenterol 1985; 88: 295302.

19. Galati EM, Monforte MT, Tripodo MM, d'Aquino A, Mondello MR. Antiulcer activity of Opuntia ficus indica (L). Mill. (Cactaceae): Ultrastructural study. J. Ethnopharmacol 2001; 76: 19.

20. Sannomiya M, Fonseca VB, DaSilva MA, Rocha LRM, dos Santos LC, Hiruma Lima CA, Souza Britto ARM, Vilegas W. Flavonoids and antiulcerogenic activity from Byrsonima crassa leaves extracts. J. Ethnopharmacol 2005; 97: 16.

21. Kokate CK, Purohit AP, Gokhale SB. Pharmacognosy. $13^{\text {th }}$ ed. Pune: Nirali Prakashan Publisher; 2007. p. 35. 
22. Dimic M, Marinkovic V, Pavlovic R, Gudzic B. Antimicrobial activity of fresh Cabbage juice Brassica oleraceae var. capitata L; 1993. http://www.amapseec.1/papers/pap 113.htm

23. Onwuchekwa C, Oluwole FS. Anti-gastric ulcer and Anti inflammatory properties of betulinic acid in male albino rats. Science World Journal 2010; 5(4): 15-117.

24. Chen SH, Pan S, Okita K, Takemoto T. Role of oxygenderived free radicals in the Mechanism of cysteamine-induced duodenal ulcer in rats. J. Formos Med. Assoc 1994; 93(1): 1114.

25. Takeuchi K, Nishikawa H, Okabe S. Role of local motility changes in the pathogenesis of duodenal ulcers induced by cysteamine in rats. Dig. Dis. Sci 1987; 32(3): 295304.

26. DevarayVC, Krishna BG. Gastric antisecretory and cytoprotective effects of leaf extract of Amaranthus tricolor Linn. in rats. Zhong Xi Yi Jie He Xue Bao 2011; 9(9): 1031-11038. http://dx.doi.org/10.3736 /jcim20110915

27. Calvo TR, Lima ZP, Silva JS, Ballesteros KVR, Pellizon CH, HirumaLima CA, Tamashiro J, Souza Britto AM, Takshira RK, Vilegas W. Constituents and antiulcer effect of Alchornea glandulosa: Activation of cell proliferation in gastric mucosa during the healing process. Biol. Pharm. Bull 2007; 30: 451459.

28. Singh P, Guha D. Aegle Nwafor PA, Okwuasaba FK. Effect of methanolic extract of Cassia nigricans leaves on rat gastrointestinal tract. Fitoterapia 2001; 72: 206214.

29. Patel KG, Patel KV, Shah RR, Yagnik RM, Gandhi TR. Evaluating antiasthmatic potential of spray driedpowder of fresh juice of leaves of Brassica oleraceae variety capitata. Res. J. Pharm. Biol. and Chem Sci 2011; 2(2): 370379.

30. Wollschlaeger B. Zinc Carnosine for the management of gastric ulcers: Clinical application and literature review. JANA 2003; 6(2): 3338.

\section{Cite this article as:}

Agbaje Esther Oluwatoyin, Okpara Chioma Sonia. Antiulcer activity of aqueous extract of fresh leaf of Brassica oleraceae Linn. Var. Acephala (D.C) Alef) (Brassicaceae). Int. Res. J. Pharm. 2013; 4(8):107-111 http://dx.doi.org/10.7897/2230-8407.04818 